\title{
TENSILE, COMPRESSIVE AND FLEXURAL STRENGTH REDUCTION OF TIMBER IN FIRE
}

\author{
Zoja Bednarek $^{1}$, Mečislavas Griškevičius ${ }^{2}$, Gintas Šaučiuvènas ${ }^{3}$ \\ ${ }^{1}$ The Main School of Fire Service (MSFS) in Warsaw, str. J. Stowackiego 52/54, \\ 01-629 Warsaw, Poland, e-mail: sgsp@sgsp.edu.pl \\ ${ }^{2}$ Department of Labour Safety and Fire Protection, Vilnius Gediminas Technical University, \\ Saulètekio al. 11, LT-10223 Vilnius, Lithuania,e-mail: m.griskevicius@vpgt.lt \\ ${ }^{3}$ Department of Steel and Timber Structures, Vilnius Gediminas Technical University, \\ Sauletekio al. 11,LT-10223Vilnius, Lithuania, e-mail: gintas.sauciuvenas@st.vgtu.lt
}

Received 1009 2009; accepted 05102009

\begin{abstract}
The present research was dedicated to investigation into the strength of timber structures under fire conditions. Two kinds of timber specimens including oak and pine were used. The carried out investigation covered static tests on tensile strength, compressive strength along the grain, compressive strength perpendicular to the grain and flexural strength. The specimens were tested under the temperatures of $50^{\circ} \mathrm{C}, 100^{\circ} \mathrm{C}$, $150^{\circ} \mathrm{C}, 200^{\circ} \mathrm{C}$ and $230^{\circ} \mathrm{C}$. The obtained results show that pine specimens have better properties over the entire temperature range in case of tests on tensile and flexural strength. Also, as for these types of strength, oak specimens show a higher strength reduction rate than those of pine specimens, whereas oak specimens have better properties over the entire temperature ranges in case of compressive strength perpendicular to the grain. Based on statistical analysis, a linear expression of the strength reduction coefficient was proposed.
\end{abstract}

Keywords: timber, wood, fire resistance, thermal analysis, strength reduction coefficient, fire test.

\section{Introduction}

A number of buildings and works of civil engineering are at high risk of fire. Therefore, an accurate prediction of the behaviour of structures subjected to fire is of primary importance for the evacuation of persons as well as for the safety of rescue teams.

Steel and concrete members (Bednarek 1996; Bednarek, Ogrodnik 2007; Gribniak et al. 2006) under fire have been extensively investigated in the last decades. However, far fewer investigations into timber structures have been conducted (Bednarek et al. 2002; Bednarek, Kaliszuk-Wietecka 2004; Frangi, Fontana 2003; Jong, Clancy 2004; Krakovský, Kral 2004; Šaučiuvenas, Griškevičius 2009). Wood is a perfect material for constructional purpose, however, it is flammable. Fire resistance to any wood structures is determined by fire resistance to its components because joints and nodes between components provide no fire resistance. Fire resistance to wood structures depends on various factors, i.e. the charring rate and charring shape, the dimensions and strength of the undamaged components.

Wood combustion characteristics and the related fire hazard are shown in Table 1 (Huntierova 1995).

The thickness of the charring rate and the charred layer are the starting points of determining the dimensions of the undamaged core at any fire time and defining temperature layout inside the core. These characteristics are important problems while learning about fire resistance to timber components using the analytical method.

The charring rate depends on a number of factors such as timber species, timber density, moisture content, chemical composition, timber defects (e.g. fissures). The charring rate also depends on actual spe- 
Table 1. Wood combustion characteristics and related fire hazard

\begin{tabular}{|c|c|c|}
\hline Material warming up & $100^{\circ} \mathrm{C}$ & Wood drying process. Loss of free water and bounded water. \\
\hline & $150^{\circ} \mathrm{C}$ & $\begin{array}{l}\text { Changes in chemicellulose and lignin. Slow reaction. Any further temperature growth } \\
\text { or keeping a constant temperature for a sufficiently long time can cause the material to } \\
\text { ignite. }\end{array}$ \\
\hline \multirow{4}{*}{$\begin{array}{l}\text { Critical temperature } \\
\text { range for material } \\
\text { decomposition }\end{array}$} & $225^{\circ} \mathrm{C}$ & The commencement of decomposition gas generation, mainly $\mathrm{CO}_{2}$, acetic acid, steam. \\
\hline & $250^{\circ} \mathrm{C}$ & Cellulose decomposition. \\
\hline & $270^{\circ} \mathrm{C}$ & $\begin{array}{l}\text { Very quick generation of decomposition products. Any occurring flame can incinerate } \\
\text { the gas mixture. }\end{array}$ \\
\hline & $290^{\circ} \mathrm{C}$ & $\begin{array}{l}\text { Wood weight loss is close to } 39 \% \text {. The material reaches temperature necessary for its } \\
\text { surface to ignite in the presence of a flame and for self-acting combustion. }\end{array}$ \\
\hline \multirow[t]{2}{*}{$\begin{array}{l}\text { Ignition temperature } \\
\text { range }\end{array}$} & $330^{\circ} \mathrm{C}$ & Flames spreading over the surface; charred layer build-up commences. \\
\hline & $400^{\circ} \mathrm{C}$ & $\begin{array}{l}\text { Exothermic course of the decomposition process. Fire transfer hazard. The maximum } \\
\text { rate of flammable gas generation. The creation of glowing layers built mainly from high- } \\
\text { energy lignin. }\end{array}$ \\
\hline \multirow[t]{2}{*}{$\begin{array}{l}\text { Combustion with open } \\
\text { fire }\end{array}$} & $450^{\circ} \mathrm{C}$ & Wood burning out inside the material. \\
\hline & $500^{\circ} \mathrm{C}$ & Charcoal residue burning. \\
\hline \multirow{2}{*}{$\begin{array}{l}\text { Glowing and complete } \\
\text { combustion of pyrolisis } \\
\text { residue }\end{array}$} & $700^{\circ} \mathrm{C}$ & The complete combustion of decomposition products (gases) on the material surface. \\
\hline & $800^{\circ} \mathrm{C}$ & The generation of flammable products is completed. \\
\hline Cooling & $1100^{\circ} \mathrm{C}$ & $\begin{array}{c}\text { The results of wood glow in the complete material destruction. Non-flammable mineral } \\
\text { residue (ash) remains. }\end{array}$ \\
\hline
\end{tabular}

cimen geometry (dimensions, shape and surface quality), heat stream density (per component surface area), the method of heat stream transport for the specimen (radiation, convection and conduction), heat operation type depending on the ignition source layout (one, two, three, four-sided thermal exposition).

Particular attention was paid to the influence of timber density on the charring rate. Schaffer (1997) suggests that timber species featuring a higher density range are specific for their lower charring rates.

The charring rate for various timber species is widely discussed in references (Huntierova 1995; Tran, White 1992; Lache 1992; Lipinskas, Mačiulaitis 2005). Besides, a discussion on the reduced charring rate versus increased timber moisture content is included.

Lithuanian Standards (LST) do not cover the issues related to structure dimensioning with regard to fire requirements. Therefore, to solve these problems, Eurocode 5 (ENV 1995-1-2: 2000) is used in Lithuania.

The present research was dedicated to investigation into the strength of timber structures under fire conditions. Two species of timber comprising oak and pine were used. The conducted investigation included static tests on tensile strength, compressive strength along the grain, compressive strength perpendicular to the grain and flexural strength. The specimens were tested under the temperatures of $50^{\circ} \mathrm{C}, 100^{\circ} \mathrm{C}, 150^{\circ} \mathrm{C}$, $200^{\circ} \mathrm{C}$ and $230^{\circ} \mathrm{C}$.

\section{Calculation of Charred Layer Thickness and the Core Strength of Timber Structure According to EC5 Principles}

Eurocode 5 (EN 1995-1-2:2004) uses the term 'an effective cross-section' which means 'the cross-section obtained by subtracting charred layer thickness from the original cross-section. The thickness of the design charred layer can be calculated as follows:

$d_{\text {char }, 0}=\beta_{0} t$,

where $d_{\text {char }, 0}$ is charred layer thickness in $\mathrm{mm} ; \beta_{0}$ is the one-dimensional design charring rate under standard fire exposure; $t$ is the time of fire exposure.

The timber charring rate, $\beta_{0}$, in the standardized heat test is assumed constant and independent from the charring process direction. The value of $\beta_{0}=0.65$ $\mathrm{mm} / \mathrm{min}$ of softwood was adopted for the analytical calculations of fire resistance. In practice, the charring 
rate varied within $0.5-0.9 \mathrm{~mm} / \mathrm{min}$ and as much as 1 $\mathrm{mm} / \mathrm{min}$ for component corners (Holm 1980).

The notional design charring depth with the effect of corner roundings can be calculated as

$d_{\text {char }, n}=\beta_{n} t$,

where $\beta_{n}$ is the notional design charring rate the magnitude of which includes for the effect of corner roundings and fissures, $t$ is the time of standard fire exposure

The thickness of the layer of no mechanical strength should be determined by the following expression:

$d_{e f}=d_{c h a r, n}+k_{0} d_{0}$

where $d_{\text {char }, n}$ is calculated using formula (2); $d_{0}=7 \mathrm{~m}$ is the thickness of the additional layer with no mechanical strength; $k_{0}$ is a coefficient taken from Eurocode 5 (EN 1995-1-2:2004).

In practice, an effective core cross-section largely resembles oval due to a higher charring rate for component corners. The oval core cross-section was taken into account in several proposed calculation models (Dębowska 2004).

While calculating bearing capacity for timber structures, reduction in material strength due to high temperature should be taken into account. Two issues should stand apart:

- temperature distribution inside the core;

- reduction in material strength due to the effect of temperature.

Thanks to its porous structure (approx. 15\% of solid material is created in timber pyrolysis), the charred layer features a low heat conductivity coefficient of approx $0.5 \mathrm{~W} / \mathrm{mK}$, thus limiting the access of both heat and oxygen to the non-charred structural component core that reduces and delays temperature growth inside the core. During the process of wood combustion, the thickness of the superficial charred layer increases at the beginning as quickly as the core dimensions decrease, and then, this process slows down due to the protective properties of the charred layer and due to the moisture evaporating into the material.

Fig. 1 shows temperature distribution across a pine board of $16 \times 36(\mathrm{~mm})$ after $60 \mathrm{~min}$.

It was determined by the performed tests that the specimens were still keeping sufficient bearing capacity and temperature in the core middle did not exceed $100^{\circ} \mathrm{C}$ in most cases. At the same time, temperature in the core reached $200^{\circ} \mathrm{C}$.

Core temperature has a significant influence on the bearing capacity of the component and fire resi-

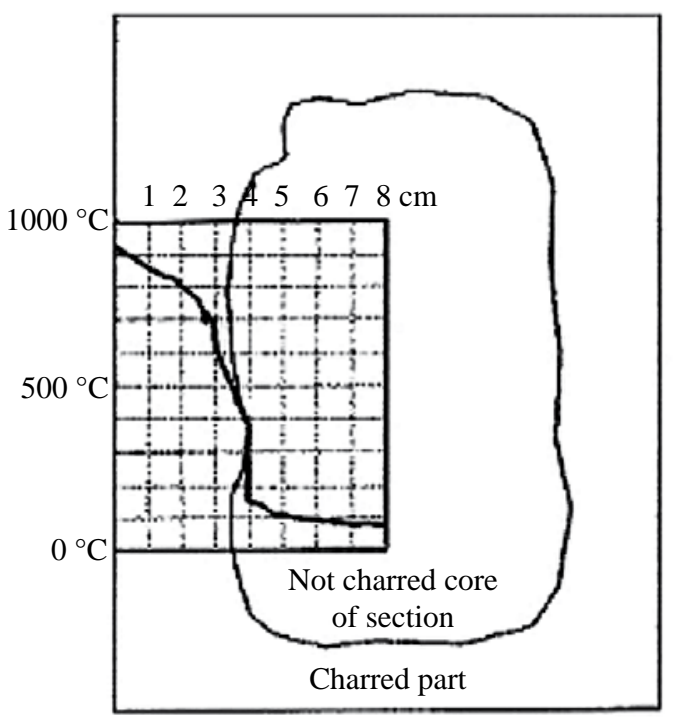

Fig. 1. Temperature distribution across the board (Holm 1980)

stance. For standard fire, the average core temperature can be determined by the following formula (ENV 1995-1-2:2000):

$T=\left(1+k \frac{b}{h}\right) \cdot\left[20+\frac{180\left(\beta t_{f}\right)^{\eta}}{(1-\eta)\left(\frac{b}{h}-\beta t_{f}\right)}\left(\left(\frac{b}{2}\right)^{1-\eta}-\left(\beta t_{f}\right)^{1-\eta}\right)\right]$, where $\eta=0.398 t_{f}^{0.62} ; b$ and $h$ are the initial width and height of the element cross-section, respectively; $t_{f}$ is fire duration time; $\beta$ is timber charring rate; $k$ is the coefficient accounting the number of sides for fire exposition:

- two-sided $k=0$;

- three-sided $k=0.25$;

- four-sided $k=0.4$.

The later expression has a good agreement with test results given in reference Kordina et al. (1994).

According to Eurocode 5, the core strength can be calculated by:

$f_{d, f i}=\frac{\left(k_{\mathrm{mod}, f i} \cdot f_{20}\right)}{\gamma_{m, f i}}$

where $f_{f, d}$ is reduced strength; $\gamma_{m, f}$ is the partial safety coefficient for fire condition equal to $1.0 ; k_{f i}$ is the coefficient accounting safety level under fire conditions for solid wood $k_{f i}=1.25 ; f_{20}$ is $20 \%$ fractile of strength property under normal temperature; $k_{\text {mod, } f i}$ is coefficient accounting strength reduction due to high temperature. 


\section{Experimental Investigation}

The main objective of the test was to investigate the influence of high temperature on the strength of timber structures. Testing results were presented in terms of coefficients making consideration on reducing wood strength under high temperatures recommended for an analytical calculation of fire resistance. The carried out investigation included the following static tests:

- tensile strength;

- compressive strength along the grain;

- compressive strength perpendicular to grain;

- flexural strength.

Static investigation was performed at the Department of Applied Mechanics in the Main School of Fire Service (MSFS) in Warsaw. A special test stand placed in the heating chamber was manufactured for this investigation.

\subsection{Thermal Investigation}

Before commencing tests, a comparative thermal investigation was performed the results of which are shown in Fig. 2. The tests were made applying the Q500 thermo gravimetric analyzer based on response to changes in substance weight considering temperature. Testing was performed in the atmosphere of environment air. The warming-up rate of $10^{\circ} \mathrm{C} / \mathrm{min}$ was adopted.

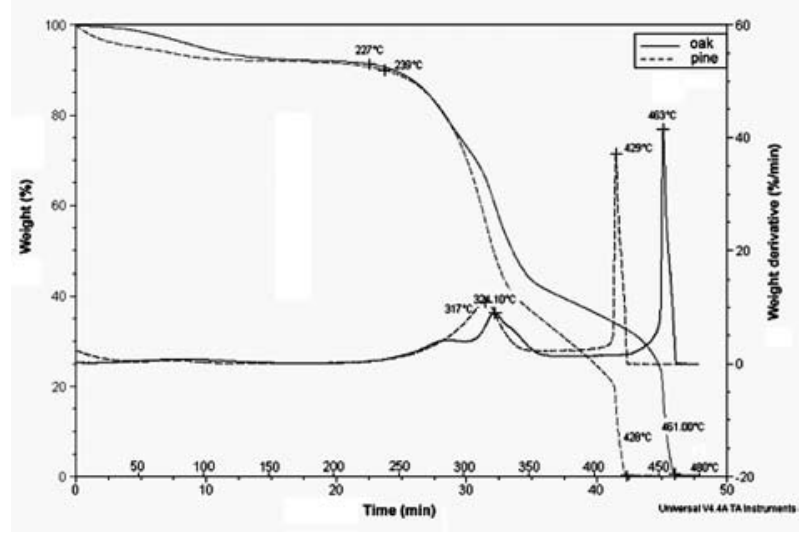

Fig. 2. Thermo graphic specimen analysis

It can be assumed for pine and oak wood specimens that thermal decomposition begins at approx. $240^{\circ} \mathrm{C}$ and follows two stages. The process is probably related to creating a charred layer reducing the thermal decomposition ratio for a certain time length. For pine wood, the weight loss is the quickest at temperature of $430^{\circ} \mathrm{C}$, whereas for oak wood it occurs at $460^{\circ} \mathrm{C}$. Pine wood self-ignition temperature was determined at ap- prox. $400^{\circ} \mathrm{C}$ and that of oak wood - at approx. $430^{\circ} \mathrm{C}$. As the given figures show, both curves for both specimens are very similar and located close to each other.

\subsection{Preparing for the Test}

The specimens were manufactured from timber without fissures. The dimension and shape of the specimens were selected according to regulation. The specimens were taken from pine and oak sapwoods. Fig. 3 shows the manner taking specimens from sapwood.

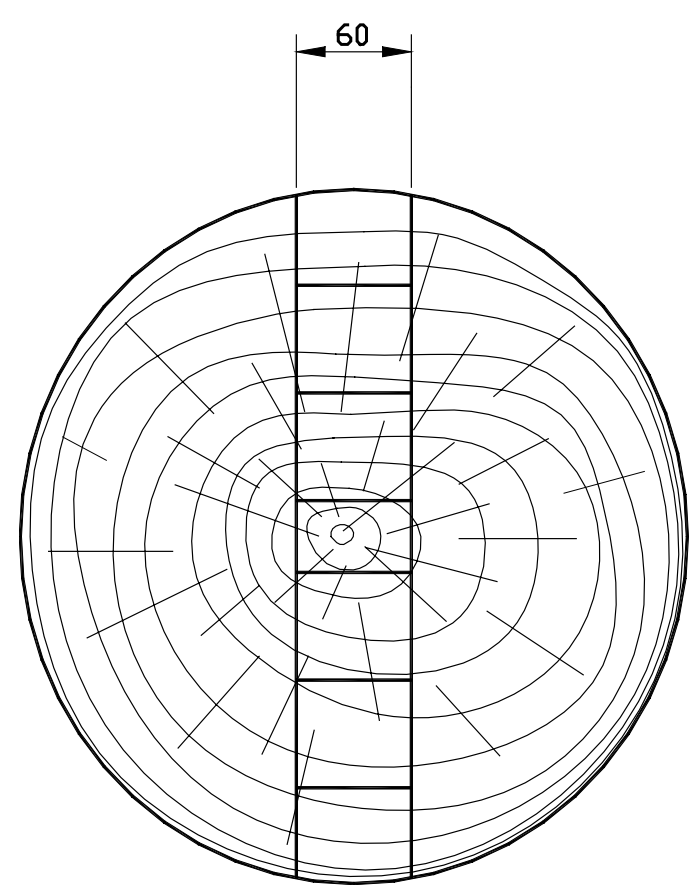

Fig. 3. Sawing specimens from sapwood

\section{Compressive strength testing}

The dimension of the specimens was $20 \times 20 \times 30$ $\mathrm{mm}$ (Fig. 4). These specimens were tested along and perpendicularly to the direction of its grain. Overall, 720 elements were manufactured (360 for testing compressive strength along the direction of the grain and 360 for testing compressive strength perpendicular to the direction of the grain).

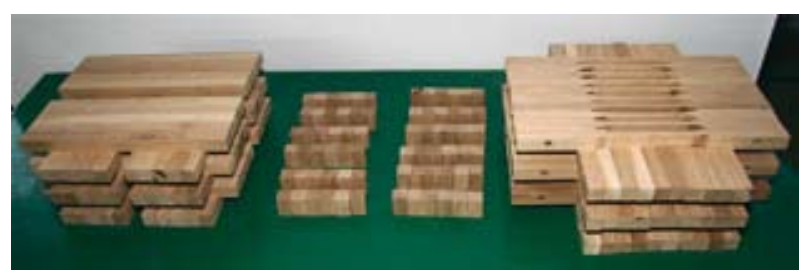

Fig. 4. Sets of the specimens for tensile, compressive and flexural tests before testing 


\section{Flexural strength testing}

The dimension of the specimens was $20 \times 20 \times 300$ $\mathrm{mm}$ (Fig. 5). Overall, 120 elements were manufactured.

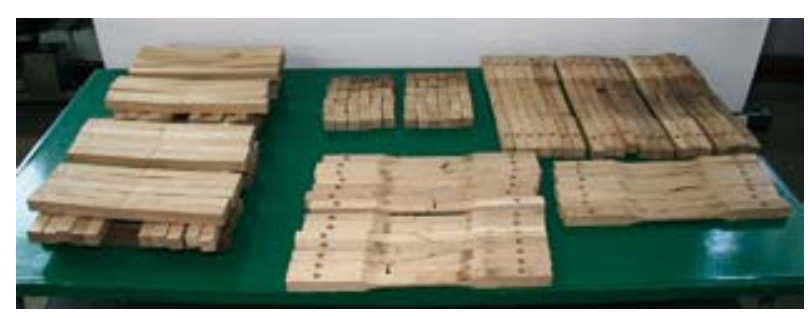

Fig. 5. Sets of the specimens for tensile, compressive and flexural tests after testing

Tensile strength testing

The shape of the specimens for tensile strength testing is shown in Fig. 6.
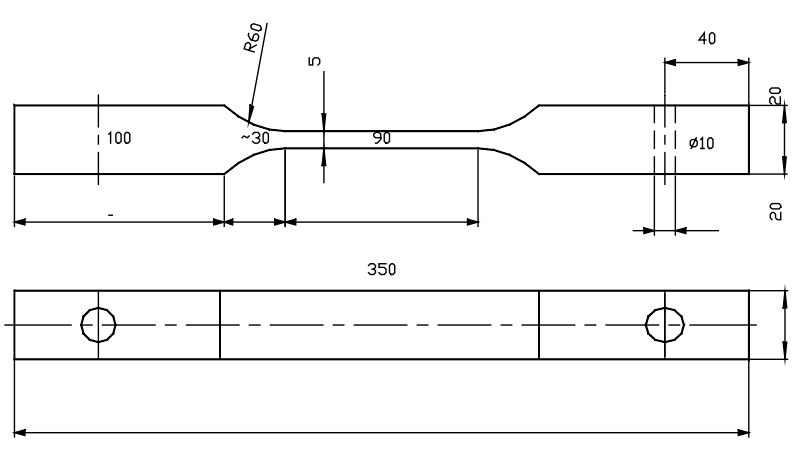

Fig. 6. Specimens for tensile strength testing

Tests were performed under the following thermal conditions:

Start temperature was approx. $20^{\circ} \mathrm{C}$ (normal temperature) within $50^{\circ} \mathrm{C}-230^{\circ} \mathrm{C}$. Taking into account that temperature increases inside the undamaged component core from $20^{\circ} \mathrm{C}$ to $200^{\circ} \mathrm{C}$ and that thermal decomposition begins at approx. $240^{\circ} \mathrm{C}$, testing temperatures were selected for determining strength reduction as follows: $50^{\circ} \mathrm{C}, 100^{\circ} \mathrm{C}, 150^{\circ} \mathrm{C}, 200^{\circ} \mathrm{C}, 230^{\circ} \mathrm{C}$.

Preliminary tests were used for determining the sample heating program in order to uniformly raise the temperature of the whole sample material.

\section{Analysis of Testing Results}

The results of strength testing collected as the average results obtained from 10 tests at high temperatures for both wood species and compared to those at $20^{\circ} \mathrm{C}$ are shown in Figures from 7 to 10.

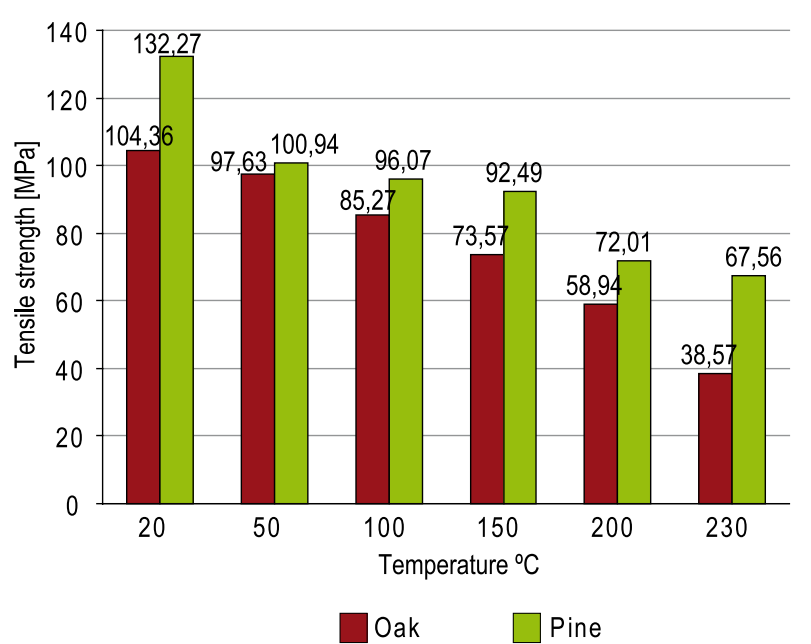

Fig. 7. Relationship of timber tensile strength along the grain and evaluated temperature

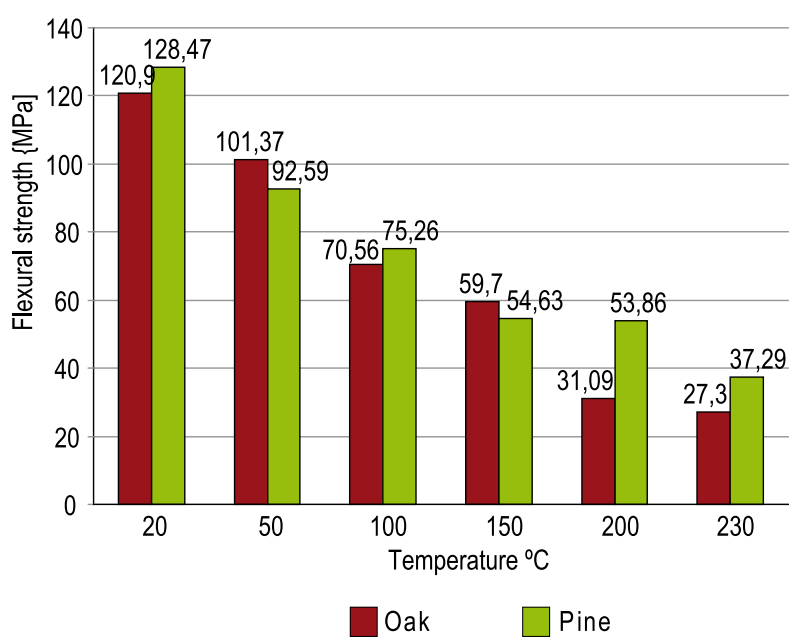

Fig. 8. Relationship of timber flexural strength and evaluated temperature

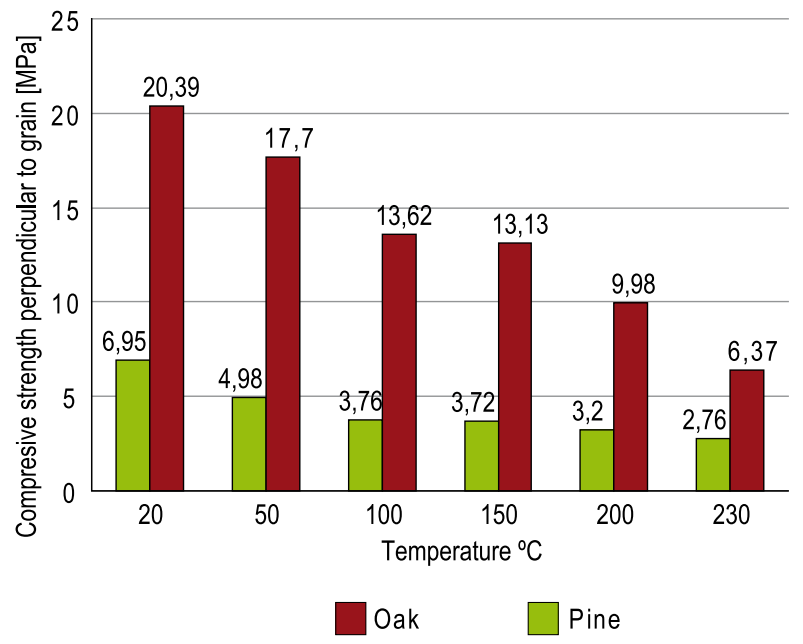

Fig. 9. Relationship of timber compressive strength perpendicular to the grain and evaluated temperaturee 


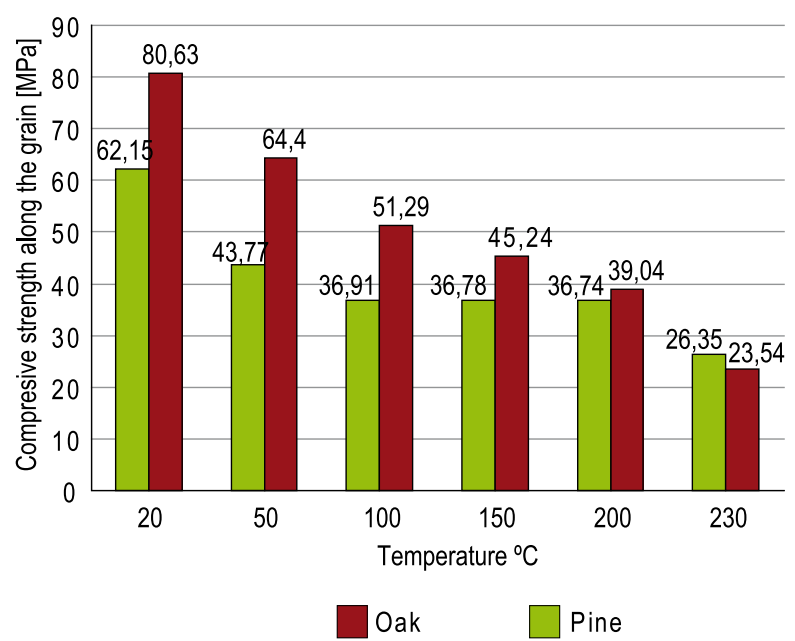

Fig. 10. Relationship of timber compressive strength along grain reduction and evaluated temperature

Reduction in strength versus temperature was defined by a linear function $y=a x+b$ for both wood species. The functions of linear regression with reliability level curves are shown in Figures from 11 to 18. Table 2 includes data (inclination, offset) on these functions and correlation coefficients equal to approx. 1.

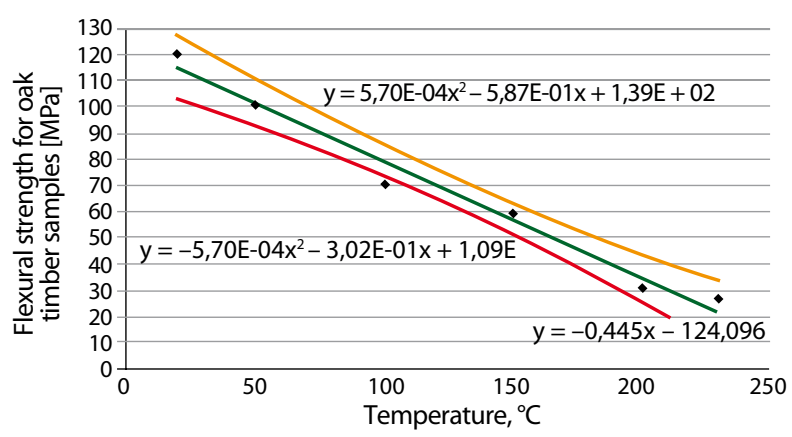

Fig. 11. Linear regression function and reliability curve for flexural strength (oak specimen)

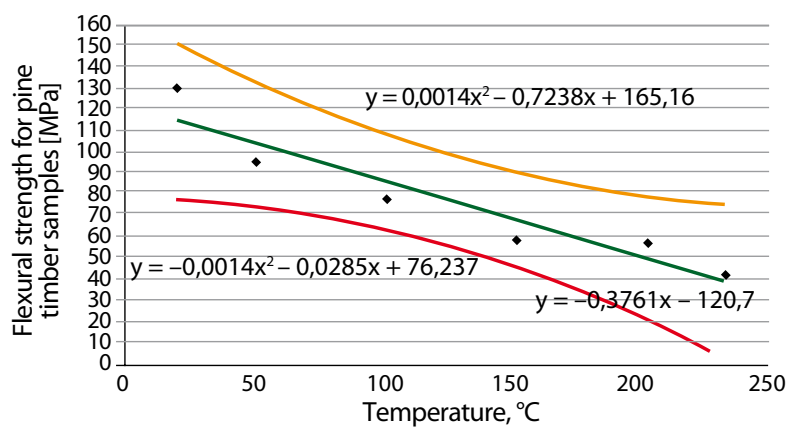

Fig. 12. Linear regression function and reliability curve for flexural strength (pine specimen)

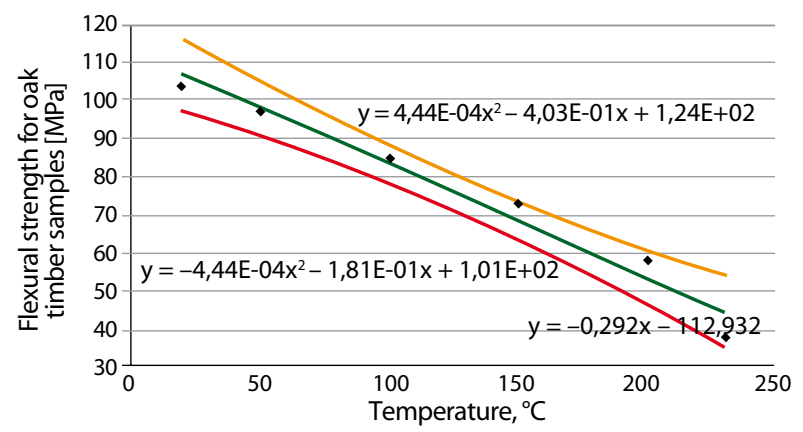

Fig. 13. Linear regression function and reliability curve for tensile strength (oak specimen)

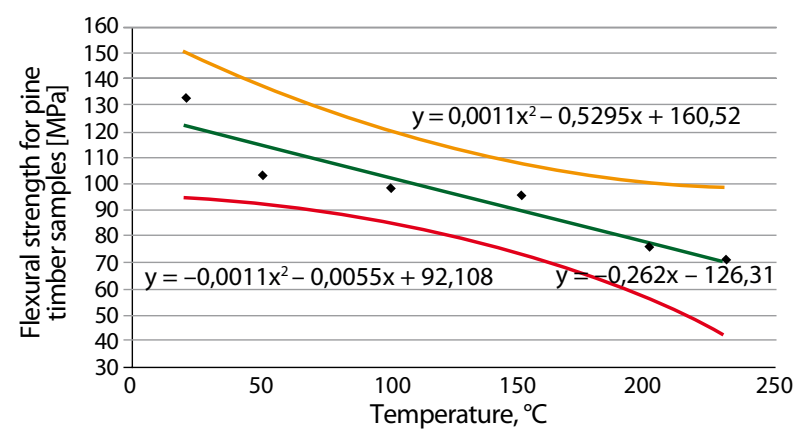

Fig. 14. Linear regression function and reliability curve for tensile strength (pine specimen)

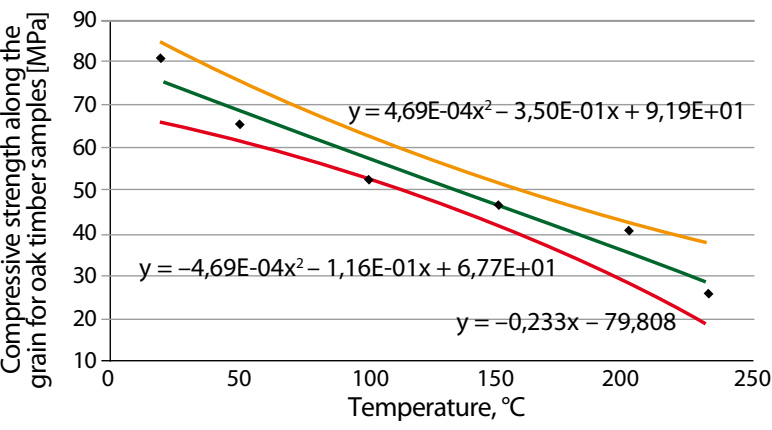

Fig. 15. Linear regression function and reliability curve for compressive strength along the grain (oak specimen)

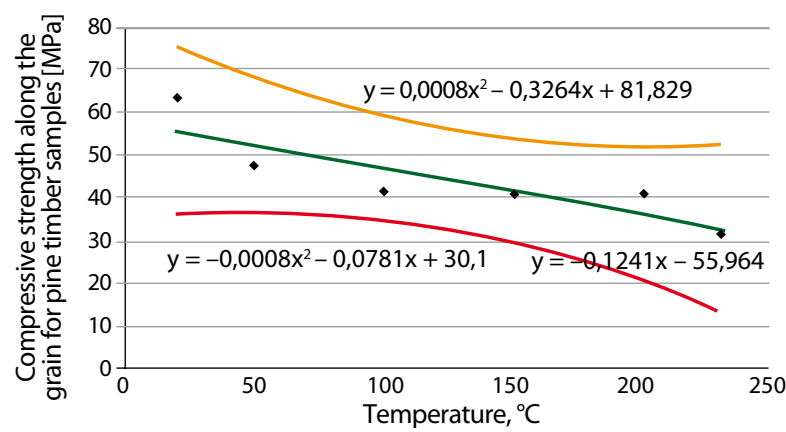

Fig. 16. Linear regression function and reliability curve for compressive strength along the grain (pine specimen) 


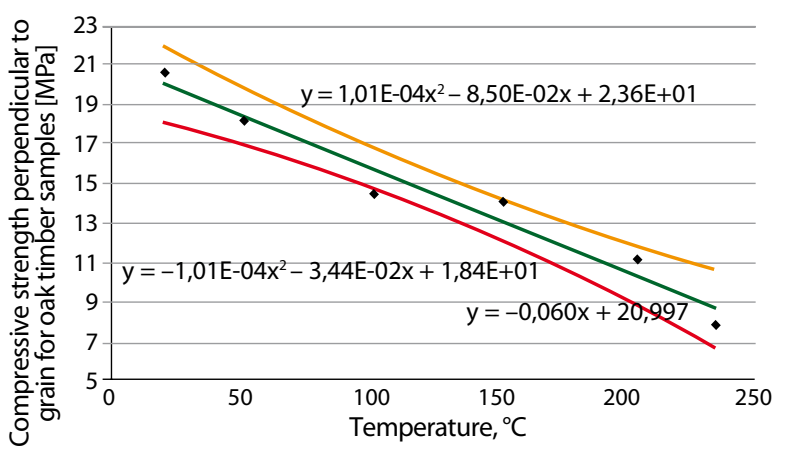

Fig. 17. Linear regression function and reliability curve for compressive strength perpendicular to the grain (oak specimen)

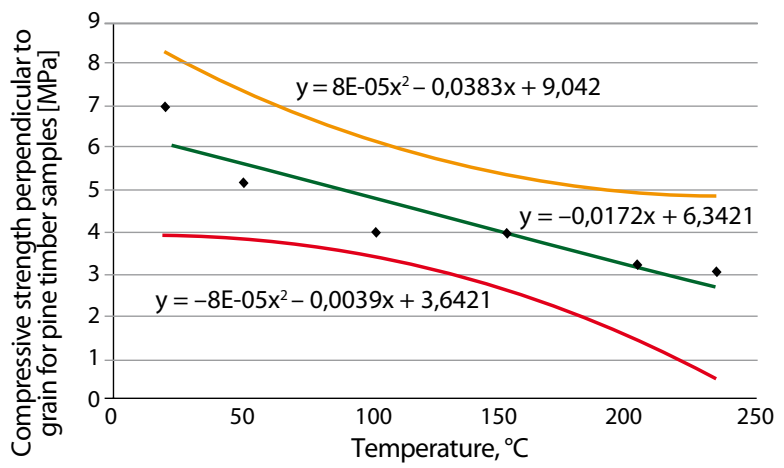

Fig. 18. Linear regression function and reliability curve for compressive strength perpendicular to the grain (pine specimen)
The graphics of the coefficient of pine and oak timber strength reduction in comparison with the curve of Eurocode 5 strength reductions are shown in Figs 19-21.

The coefficients of strength reduction, $k_{\bmod f i}$ based on the analysis of testing results were proposed. These coefficients should be applied for calculating the strength of timber elements in fire according to Eurocode 5 (EN 1995-1-2:2004). The proposed values of reduction coefficients are included in Table 3. A comparison of the reduction coefficients of compressive strengths with data obtained by other authors (König 2000) is given in Fig. 22.

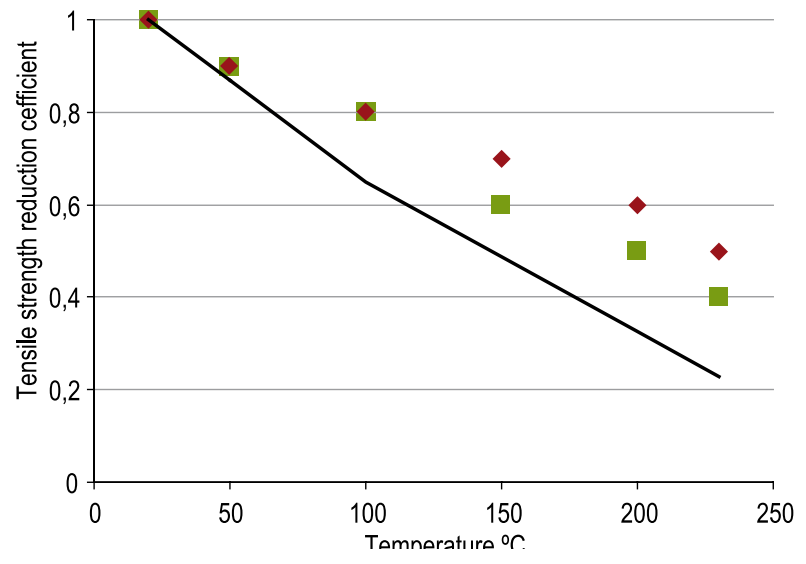

Fig. 19. Relationship between strength reduction coefficients $k_{\bmod f i}$ and tensile strength along the grain

Table 2. Comparison of regression function and correlation coefficients considering the selected type of testing

\begin{tabular}{|c|c|c|c|c|c|c|c|}
\hline \multirow{4}{*}{ No. } & \multirow{4}{*}{ Testing type } & \multicolumn{4}{|c|}{ Coefficients of regression function: $y=a x+b$} & \multirow{2}{*}{\multicolumn{2}{|c|}{$\begin{array}{l}\text { Correlation coefficient } \\
\text { of thermal timber } \\
\text { strength }\end{array}$}} \\
\hline & & \multirow{2}{*}{\multicolumn{2}{|c|}{$\begin{array}{c}\text { Regression function declination - } \\
\text { coefficient } a \\
\text { Specimen group }\end{array}$}} & \multirow{2}{*}{\multicolumn{2}{|c|}{$\begin{array}{c}\text { Regression function declination - } \\
\text { coefficient } b \\
\text { Specimen group } \\
\end{array}$}} & & \\
\hline & & & & & & Speci & group \\
\hline & & Pine & Oak & Pine & Oak & Pine & Oak \\
\hline 1 & Tension & -0.262 & -0.292 & 126.312 & 112.932 & 0.9372 & 0.9833 \\
\hline 2 & Bending & -0.376 & -0.445 & 120.696 & 124.096 & 0.9477 & 0.9880 \\
\hline 3 & $\begin{array}{c}\text { Compression along } \\
\text { the grain }\end{array}$ & -0.124 & -0.233 & 55.964 & 79.808 & 0.8598 & 0.9712 \\
\hline 4 & $\begin{array}{l}\text { Compression } \\
\text { perpendicular to the } \\
\text { grain }\end{array}$ & -0.017 & -0.06 & 6.342 & 20.997 & 0.9126 & 0.9793 \\
\hline
\end{tabular}

Table 3. Strength reduction coefficient $k_{\bmod f}$

\begin{tabular}{|c|c|c|c|c|c|c|c|c|}
\hline \multirow{2}{*}{$\begin{array}{c}\text { Temperature } \\
{\left[{ }^{\circ} \mathrm{C}\right]}\end{array}$} & \multicolumn{2}{|c|}{ Bending } & \multicolumn{3}{c|}{ Tension } & \multicolumn{2}{c|}{$\begin{array}{c}\text { Compression along the } \\
\text { grain }\end{array}$} & \multicolumn{2}{c|}{$\begin{array}{c}\text { Compression } \\
\text { perpendicular to grain }\end{array}$} \\
\cline { 2 - 10 } & Pine & Oak & Pine & Oak & Pine & Oak & Pine & Oak \\
\hline 20 & 1.0 & 1.0 & 1.0 & 1.0 & 1.0 & 1.0 & 1.0 & 1.0 \\
\hline 50 & 0.9 & 0.9 & 0.9 & 0.9 & 0.9 & 0.9 & 0.9 & 0.9 \\
\hline 100 & 0.7 & 0.7 & 0.8 & 0.8 & 0.8 & 0.8 & 0.8 & 0.8 \\
\hline 150 & 0.6 & 0.5 & 0.7 & 0.6 & 0.7 & 0.6 & 0.6 & 0.6 \\
\hline 200 & 0.4 & 0.3 & 0.6 & 0.5 & 0.6 & 0.4 & 0.5 & 0.5 \\
\hline 230 & 0.3 & 0.2 & 0.5 & 0.4 & 0.5 & 0.3 & 0.4 & 0.4 \\
\hline
\end{tabular}




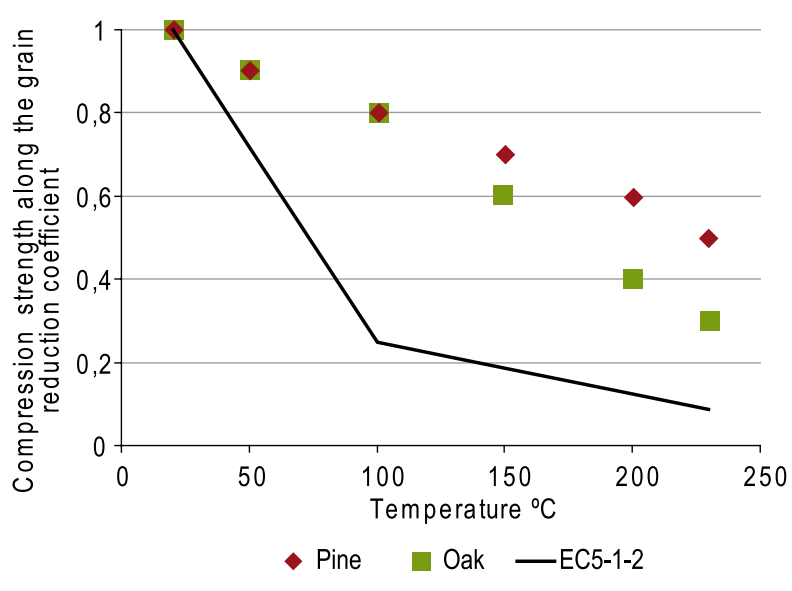

Fig. 20. Relationship between strength reduction coefficients $k_{\bmod f i}$ and compression strength along the grain

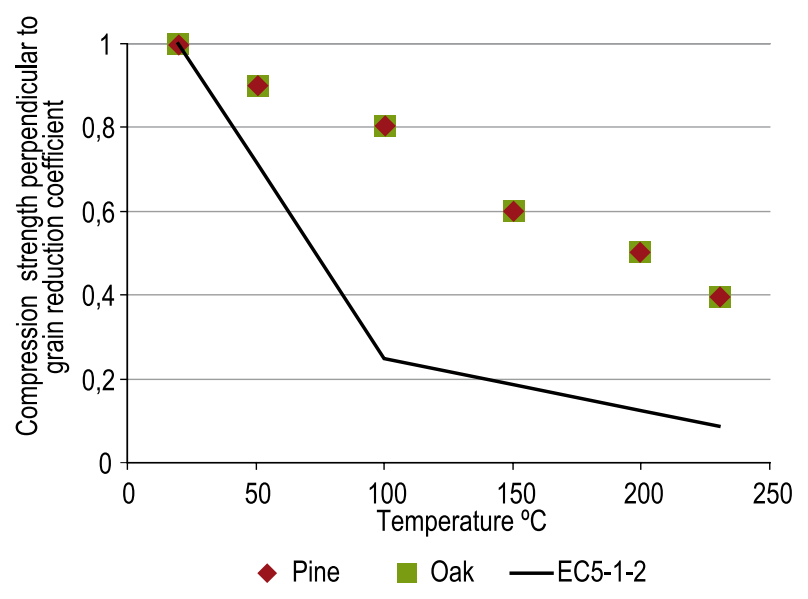

Fig. 21. Relationship between strength reduction coefficients $k_{\bmod i}$ and compression strength perpendicular to the grain

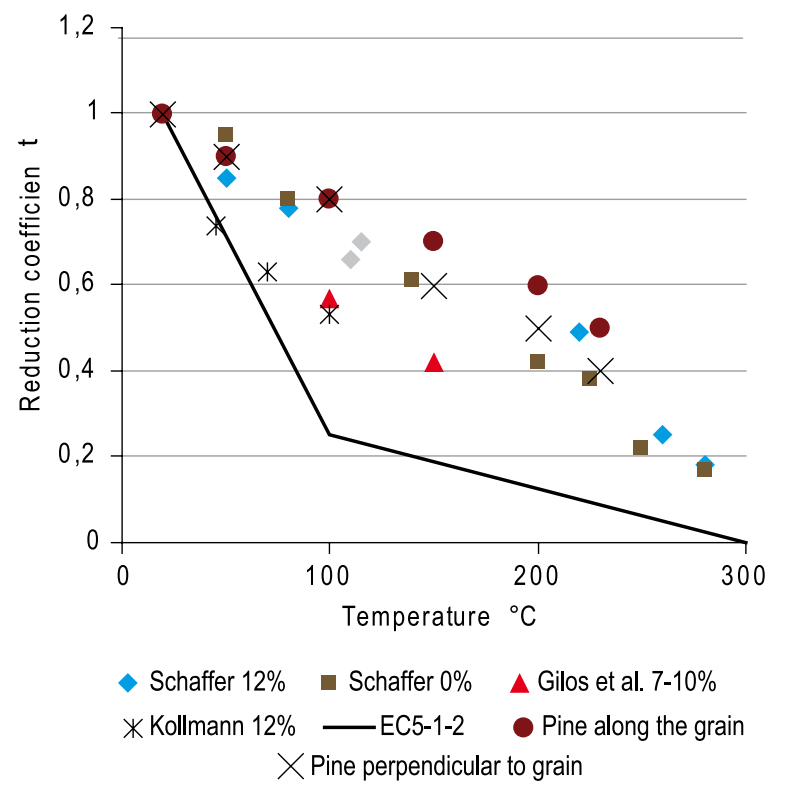

Fig. 22. Reduction in compressive strength

\section{Concluding Remarks}

This study was conducted to investigate fire resistance to timber specimens (pine and oak). The following conclusions can be drawn:

A significant influence of even low growth in temperature on all strength types was observed. From the point of view of fire resistance evaluation, temperature rise in the range between 100 and $200^{\circ} \mathrm{C}$ is important.

The results of thermal analysis have showed similar fire profiles (flammability) of both wood specimens. Thermal decomposition begins at $240^{\circ} \mathrm{C}$ in both cases; the highest mass loss rate occurred at approx. $430^{\circ} \mathrm{C}$ after 42 minutes for pine and at approx. $460^{\circ} \mathrm{C}$ after 47 minutes for oak. Self-ignition occurred at approx. $400^{\circ} \mathrm{C}$ for pine and at $430^{\circ} \mathrm{C}$ for oak. TG and DTG curves were similar.

Oak specimens have an undisputable advantage over pine specimens at normal as well as elevated temperatures for compressive strength perpendicular to the grain; nevertheless, tests proved that the rate of strength reduction versus temperature was higher in the oak samples. For compressive strength along the grain, oak specimens have higher values than those of pine within the entire range of temperature; still, a higher rate of strength reduction versus temperature was also found analyzing oak specimens.

The above observations give reasons for stating that oak specimens (of a higher density than that of pine specimens) react with a more rapid strength reduction against the rising temperature rather than those of pine.

For calculating wood strength in fire temperatures for both species of wood, it is proposed to apply regression functions as shown in Figures from 11 to 18 or refer to the data included in Table 2. The conducted testing discloses that strength reduction against rising temperature has a linear character.

To evaluate the structures of fire resistance to timber, strength reduction coefficients, $k_{\bmod f i}$, as listed in Table 3 , are proposed for application.

\section{References}

Bednarek, Z. 1996. Determination of the temperature of uncovered steel constructions using numerical methods, Statyba [Civil Engineering] 4(8): 6-10.

Bednarek, Z.; Kaliszuk-Wietecka, A.; Wiśniewski, T. 2002. Research on the influence of fire protection impregnation carried out by the vacuum -and-pressure method on wood dynamic strength, Building Review [Przegląd Budowlany] 10: 12-14 (in Polish).

Bednarek, Z.; Kaliszuk-Wietecka, A. 2004. Scientific research on the influence of fireproof wood preservation carried out by 
the vacuum-pressure method on strength of wood in normal and elevated temperatures, in Proceedings of the 8th International Conference "Modern Building Materials, Structures and Techniques”, Vilnius, 19-21 May 2004. Vilnius, 963-967.

Bednarek, Z.; Ogrodnik, P. 2007. Testing steel-concrete bond in fire conditions, in Proceedings of the 9th International Conference "Modern Building Materials, Structures and Techniques", Vilnius, 16-18 May 2007. Vilnius, 1152-1158.

Dębowska, A. 2004. Problems of wood steel constructions in fire. Polytechnic Opole (in Polish).

ENV 1995-1-2:2000 Eurocode 5: Design of timber structures. Part 1-2: General rules Structural fire design. Brussels.

EN 1995-1-2:2004 Eurocode 5: Design of timber structures. Part 1-2: General-Structural fire design. Brussels.

Frangi, A.; Fontana, M. 2003. Charring rates and temperature profiles of wood sections, Journal of Fire and Materials 27(2): 91-102. doi:10.1002/fam.819

Gribniak, V.; Bacinskas, D.; Kaklauskas, G. 2006. Numerical simulation strategy of reinforced concrete tunnel bearing members in fire, The Baltic Journal of Road and Bridge Engineering 1(1): 5-9.

Jong, F.; Clancy, P. 2004. Compression properties of wood as functions of moisture, stress and temperature, Journal of Fire and Materials 28(2-4): 209-225. doi:10.1002/fam.859

Holm, C. 1980. A survey of the goals and results of fire endurance investigations especially from the viewpoint of glued laminated structures, in Symposium in Tbilisi "Fire Resistance of Wood Structures", Tbilisi, 17-24.

Huntierova, Z. 1995. Analysis of the burning behavior of wood and timber considering the use of fire protection layers. $\mathrm{Mu}-$ nich: Graefelfing publishing house (in German).

Kordina, K.; Meyer-Ottens, C.; Scheer, C. 1994. Handbook of wood fire safety. Munich: Ernst and Son (in German).

Krakovský, A.; Kral, Š. 2004. The influence of thermo mechanical loading on behavior of spruce wood. Technical University in Zvolen (in Polish).

Lache, M. 1992. A survey of the burning rate of solid wood and the fire resistance of wooden ceiling boards exposed to bending. Munich (in German).

Lipinskas, D.; Mačiulaitis, R. 2005. Further opportunities for development of the method for fire origin prognosis, Journal of Civil Engineering and Management 11(4): 299-307.

Šaučiuvenas, G.; Griškevičius, M. 2009. The behavior or axial compression timber elements at fire, Statybines konstrukcijos ir technologijos [Engineering Structures and Technologies] 1(1): 50-57 (in Lithuanian). doi: 10.3846/skt.2009.06

Schaffer, E. 1997. State of structural timber fire endurance, Wood and Fiber 9(2): 145-170.

Tran, H. C.; White, R. H. 1992. Burning rate of solid wood measured in a heat release rate colorimeter, Fire and Materials 16: 197-206. doi:10.1002/fam.810160406

\section{MEDIENOS TEMPIAMOJO, GNIUŽDOMOJO IR LENKIAMOJO STIPRIO MAŽĖJIMAS GAISRO SĄLYGOMIS}

\section{Z. Bednarek, M. Griškevičius, G. Šaučiuvènas}

Santrauka. Straipsnyje nagrinèjami dviejų rūšių medienos stiprumo tyrinejjimo, veikiant aukštai temperatūrai, rezultatai. Tyrimams buvo naudojama ąžuolo ir pušies mediena. Ištirtas aukštos temperatūros poveikis šių medienos rūšių stiprio rodikliams. Tyrimų metu buvo taikyti tokie bandinių bandymo būdai: medienos tempimas išilgai pluošto, gniuždymas išilgai pluošto, gniuždymas skersai pluošto bei lenkimas. Statiniai tyrimai atlikti tokiose temperatūrose: $20^{\circ} \mathrm{C}, 50^{\circ} \mathrm{C}, 100^{\circ} \mathrm{C}, 150^{\circ} \mathrm{C}$, $200^{\circ} \mathrm{C}$ ir $230^{\circ} \mathrm{C}$. Tyrimų rezultatai rodo, kad tempiant ir lenkiant pušies mediena pasižymi geresnemis stiprumo savybemis visame temperatūrų diapazone. Taikant šiuos bandymo būdus ąžuolo bandiniu atspario mažejimo koeficientai yra didesni negu pušies bandinių. Kalbant apie gniuždymą išilgai pluošto, tai ąžuolo medienos atsparis visame temperatūrų diapazone yra didesnis už pušies. Remiantis statistine analize buvo pateiktas medienos stiprio mažèjimo koeficiento ir temperatūros sąryšis.

Reikšminiai žodžiai: mediena, gniuždymas, tempimas, lenkimas, gaisras, temperatūra, stiprio mažejimas.

Zoja BEDNAREK. Prof. Dr Sc., the Rector of the Main School of Fire Service in Warsaw, Poland. A member of PN-TTE Polish Maintenance Society. Research interests: the strength of materials and the behaviour of building structures at elevated temperatures. A promoter of Doctoral thesis concerning the problems mentioned above.

Mečislovas GRIŠKEVIČIUS. A lecturer at the Department of Labour Safety and Fire Protection, Vilnius Gediminas Technical University. Research interests: fire prevention services, organization and implementation of lifesaving work.

Gintas ŠAUČIUVĖNAS. Assoc. Prof. Dr at the Department of Steel and Timber Structures of Vilnius Gediminas Technical University. Research interests: evaluation of the existing steel and timber structures, evaluation of fire resistance to steel and timber structures. 